\title{
Predicting locally grown food purchase intention of domestic and international undergraduate hospitality management students at a Canadian University
}

\author{
Yoonah Kim Conoly
}

Department of Nutrition, Dietetics, and Hospitality Management, Auburn University, Auburn, Alabama, USA

Mike von Massow

Food, Agricultural and Resource Economics, University of Guelph, Guelhh, Canada, and

Yee Ming Lee

Department of Nutrition, Dietetics, and Hospitality Management, Auburn University, Auburn, Alabama, USA

\begin{abstract}
Purpose - This study aims to investigate how domestic and international undergraduate students from a university in Ontario, Canada, defined locally grown food and examined the factors behind their locally grown food purchase intentions.

Design/methodology/approach - Questionnaires were distributed in the School of Hospitality, Food, and Tourism Management undergraduate classes. A total of 196 complete surveys were returned. Using multiple regression analysis and theory of planned behavior (TPB) as a theoretical framework with an additional construct, moral norm, proposed hypotheses were tested.

Findings - Domestic students narrowly defined locally grown food based on distance (e.g. food grown/raised within $100 \mathrm{~km}$ of where a person lives) compared to international students (e.g. food grown in Canada). The multiple regression analysis revealed that $36 \%$ of variance in purchase intention is explained by the four independent variables (i.e. student status, attitude, perceived product availability and moral norm), with perceived product availability as the strongest predictor of intention to purchase locally grown food.

Research limitations/implications - The convenience sampling method limitations are as follows. First, the sample size was small for international students. Second, there was a possibility of underrepresentation of certain origins of international student populations. Third, the undergraduate respondents were from the School of Hospitality, Food and Tourism. Finally, another limitation is that the four variables in this study (i.e. attitudes, subjective norms, perceived product availability, and moral norm) only explained $36 \%$ of the variance of this model.

Practical implications - Perceived product availability, moral norm and attitude constructs positively influenced the locally grown food purchase intention. A perceived product availability construct revealed the strongest influence in locally grown food purchase intention of students. Particularly, five key questions were created based on the major research findings of this study, which can be used as a guideline for locally grown food providers and farmers when promoting locally grown food to students. These questions include: Where can I find it? When can I find it? Who grows it? How can I benefit others? Why is it good for me?
\end{abstract}

(C) Yoonah Kim Conoly, Mike von Massow and Yee Ming Lee. Published in International Hospitality Review. Published by Emerald Publishing Limited. This article is published under the Creative Commons Attribution (CC BY 4.0) licence. Anyone may reproduce, distribute, translate and create derivative works of this article (for both commercial and non-commercial purposes), subject to full attribution to the original publication and authors. The full terms of this licence may be seen at http:// creativecommons.org/licences/by/4.0/legalcode
Locally grown

food purchase intention

Received 5 February 2021 Revised 26 April 2021 17 June 2021 
Social implications - The results of this study shown that which factors influence locally grown food purchase intention of students. Hence, local restaurateurs and university dining facilities may incorporate these factors in their marketing message to serve students population better who might be interested in buying food products using locally grown ingredients. Research results also allow local farmers to communicate and inform their current and potential student consumers about the advantages of locally grown food. Overall, findings can contribute to economy and business of local community.

Originality/value - Current research findings verified that there is a significant use of a moral norm construct to predict locally grown food purchase intention of students. The moral norm construct positively influenced the locally grown food purchase intention in this study, and this construct seemed useful to predict locally grown food purchase intention of students. Additionally, the research discovered that there were differences in domestic and international undergraduate students' perception in the locally grown food definition.

Keywords Locally grown food, Purchase intention, Domestic students, International students,

Theory of planned behavior

Paper type Research paper

\section{Introduction}

Consumers' demand for locally grown or produced food has been increasing in developed countries (Bianchi and Mortimer, 2015; Jones et al., 2004; Morris and Buller, 2003; Penney and Prior, 2014). In Canada, $48 \%$ of consumers stated that they somewhat agreed to make an effort to purchase food produced or grown locally (Statista Research Department, 2015a), and $71 \%$ of customers were willing to pay more for it (Statista Research Department, 2015b). Ninety-one percent of customers stated the farmers markets are the best place to purchase locally grown food (Statista Research Department, 2015c). However, 39\% of consumers stated that absence of in-store promotions on local food discouraged them from buying locally grown food (Statista Research Department, 2015d).

Demand for locally grown food on college campuses is also increasing, as is evident by the fact that campus dining services have included locally grown food in their menus (Maynard et al., 2018). For example, some of the menu items from a campus dining facility located in Ontario, Canada, are created based on selected ingredients from this province, which includes $100 \%$ local-beef burgers and a variety of condiments (Kenny, 2014). The relationships between locally grown food and general consumers have been studied for 3 decades to understand the drivers of their purchase behaviors (Bianchi and Mortimer, 2015; Bruhn et al., 1992; Chambers et al., 2007; Dukeshire et al., 2014; Feagan et al., 2004; Onozaka et al., 2010; Penney and Prior, 2014). However, limited studies have been conducted among college students who have increased their interest in locally grown food. Because the millennial generation has great future market potential due to their purchasing power, environmental concerns and characteristics (Farris et al., 2002; Neuborne and Kerwin, 1999), the topics related to students' intention to buy locally grown food needs to be explored further.

Furthermore, many previous studies have offered definitions of locally grown food (Brooker et al., 1987; Brown, 2003; Conner et al., 2010; Eičaitè and Dabkienè, 2015; Wilkins et al., 2000; Wilkins, 2002; Zepeda and Leviten-Reid, 2004). However, there is no distinct, universal definition of locally grown food currently accepted (Bianchi and Mortimer, 2015; Chambers et al., 2007; Jones et al, 2004; Lang and Qu Gardyn, 2014). Also, there is only a limited definition offered student consumers (Wilkins et al, 2000). Understanding how locally grown food is viewed by students can help researchers and stakeholders of locally grown food (i.e. growers) better define its context (Wilkins et al, 2000). In addition, data from the Immigration Refugees and Citizenship Canada (IRCC) showed that there were 642,480 foreign students in Canada as of December 31, 2019, which was a 13\% rise compared to 2018 (Cbie-Bcei, 2020). This foreign student constituent could represent a new market for locally grown food (Maynard et al., 2018).

Based on the discussions above, the purpose of this research was to investigate how domestic and international students from the hospitality program of a Canadian University perceived locally grown food. The specific objectives were to (1) explore how these two 
student groups define locally grown food and (2) examine and compare the factors behind the locally grown food purchase intentions of two groups of students using the theory of planned behavior (TPB). Based on the objectives of this study, the following research questions were examined:

(1) How do undergraduate hospitality management students in Canada define locally grown food?

(2) Is there a difference in how domestic and international undergraduate hospitality management students define locally grown food in Canada?

(3) What are the predictors of both domestic and international undergraduate hospitality management students' intentions to purchase locally grown food in Canada?

(4) What are the most influential predictors of domestic and international undergraduate hospitality management students' intentions to purchase locally grown food in Canada?

(5) Are there differences between domestic and international undergraduate hospitality management students' perceptions of locally grown food in Canada?

Discovering the perception (i.e. definition) and factors associated with purchase intentions of locally grown food among both domestic and international students at universities could provide better marketing strategies for local food growers, suppliers, universities and food retailers serving the campus community. More importantly, different messages and more targeted strategies could be planned for these two student groups based on the differences revealed by this study.

\section{Literature review}

\subsection{Definition of locally grown food}

In a broader sense, locally grown food is defined as "the direct or intermediated marketing of food to consumers that is produced and distributed in a limited geographic area." by National Agricultural Library (NAL) of the United States Department of Agriculture (USDA) (NAL, 2021). Direct marketing connects consumers to farms or known sources of products. Meanwhile, intermediate marketing is associated with point-of-sales that allows producers to sell farm products to buyers such as food retailers (e.g. restaurants, grocery stores, specialty stores, etc.), distributors and other types of foodservices (Wisconsin Local Food Marketing Guide, 2014). Within the context of geographical area, the existing literature tend to include the distance from producer to consumer or the jurisdiction identifier, such as the name of a province (Brooker et al., 1987; Brown, 2003; Conner et al., 2010; Eičaitė and Dabkienė, 2015; Wilkins et al., 2000; Wilkins, 2002; Zepeda and Leviten-Reid, 2004). However, there is no distinct universal definition of locally grown food currently accepted (Bianchi and Mortimer, 2015; Chambers et al., 2007; Jones et al., 2004; Lang and Qu Gardyn, 2014).

The Food, Conservation, and Energy Act of 2008 from the USDA Economic Research Service (ERS) defines locally grown food as food that has to travel no more than 400 miles from the place of its origin to the consumer or can originally grow in the consumer's state (Martinez et al., 2010). The Canadian Food Inspection Agency (CFIA) adopted a slightly different definition, which recognizes local as: "food produced in the province or territory in which it is sold, or food sold across provincial borders within $50 \mathrm{~km}$ of the originating province or territory" (Government of Canada, 2014). Although differing in specific details, the similarity between the definitions is that they are both based on travel distances and origin of food.

Other units of analysis have also been used to define local, including political boundaries such as provinces, countries, states and regions are frequently used (Herrin and Gussow, 
1989; Wilkins et al., 1996). Using political boundaries as the unit of analysis was based on the fact that agricultural production data and population statistics are collected in this manner by provinces, states, countries and regions (Wilkins, 2002). Conner et al. (2010) observed consumers' definition of locally grown food at farmer's market Michigan, USA. Consumers defined locally grown food as grown within state e.g. Michigan. In a case of Europe, $54.7 \%$ of Lithuanian residents stated locally grown food as produced within more than $100 \mathrm{~km}$ from their residence (Eičaitè and Dabkienè, 2015), whereas households from Southeast Missouri, USA, defined locally grown food as regional concept - e.g. southeast Missouri region rather than the statewide concept e.g. Missouri (Brown, 2003).

Zepeda and Leviten-Reid (2004) discovered different demographic groups may define local food differently. For example, while most of Caucasian groups' definitions were based on distance (e.g. driving time) and political boundaries (e.g. within a state), African American participants from one conventional shoppers' group defined locally grown food in much larger political boundaries (e.g. nearby states and within the USA) (Zepeda and Leviten-Reid, 2004). In addition, three African American participants' definitions were based on more personal context as compared to Caucasian groups. For instance, the definition of locally grown food as described by three African American participants was that locally grown food is produced by someone they know or produced from a relative's garden (Zepeda and LevitenReid, 2004).

In the case of students, Wilkins et al. (2000) observed the awareness, usage and meaning of a term "local food" at a university in USA. According to Wilkins et al. (2000), 75\% of students had heard the term "local food" but only $27 \%$ of students used it. More than half $(65 \%)$ of students' interpretations of "local food" were mainly related to the place of food production (Wilkins et al., 2000). One recent study of Aprile et al. (2016) noted that no commonly recognized single definition of "local" currently exists. Overall, there are different definitions of locally grown foods. Furthermore, there is little empirical research on the relationship between undergraduate students in Canadian context and the definition of locally grown food. Most importantly, undergraduate university students from Ontario, Canada, want high-quality and locally sourced food when they dine at campus (Bueckert, 2018). Thus, discovering the perception of Canadian undergraduate university students on locally grown food, such as their definition of locally grown food, is necessary as it can benefit university cafeterias to observe their awareness of locally grown food.

\subsection{Social, health, environment and economic benefit of locally grown food}

Previous research on locally grown food was able to identify four benefits of local food: social, health, environmental and economic. Feagan (2007) explained the social benefit of locally grown food with the idea that local food system (LFS) can act as reattachment to place and strengthen people's identity. "As our identities are seemingly threatened by physically lengthening food chains and the place-disruption that ensues with modern agricultural systems, the LFS movements portend or offer some psychological solutions or antidotes to this 'thinning' the reconstitution of homo-geographicus" (Feagan, 2007, p. 37). Pretty (2001) mentioned that LFS can bring social benefit by creating more connection and trust between food providers and consumers at the UK. Social benefit of locally grown food contributes to a reconnecting the relationship between producers and consumers, which can lead to better understanding between urban and rural residents (Pearson et al., 2011).

Health benefits of locally grown food is one of the important drivers that encourage consumers to consume locally grown food from previous findings (Bianchi and Mortimer, 2015; Eičaite and Dabkienè, 2015). For environmental benefit, Conner et al. (2010) stated that consumers' interest for locally grown food is increasing because they advocate food systems that are more sustainable. From the economic standpoint, Pearson et al. (2011) concluded that 
locally grown food brings economic benefit by revitalizing local service, horticultural practices and food infrastructures/supply chains at local community. Sacks (2002) explained that money spent to purchase locally grown produce tends to remain longer in the local community, thus contributing to local economy growth. intention

\subsection{Drivers and barriers consuming locally grown food}

Drivers and barriers to the purchase or consumption of locally grown food have been critically investigated (Bianchi and Mortimer, 2015; Bruhn et al., 1992; Chambers et al., 2007; Dukeshire et al., 2014; Feagan et al., 2004; Onozaka et al., 2010; Penney and Prior, 2014). Weatherell et al. (2003) found that the reasons to purchase locally grown food can be divided into personal motivation or social motivation. Personal drivers to locally grown food include enhanced taste, freshness and superiority of produce (Bianchi and Mortimer, 2015; Bruhn et al., 1992; Chambers et al., 2007; Murphy, 2011; Onozaka et al., 2010; Penney and Prior, 2014). When it comes to social motivations, major social drivers to locally grown food are support for local community's economy and local producers (Bruhn et al., 1992; Chambers et al., 2007; Onozaka et al., 2010; Penney and Prior, 2014; Weatherell et al., 2003). Dodds et al. (2014) found that both social (support for local community) and personal preferences (e.g. product quality) are the main motivators for consumers to shop at farmers' markets in Toronto, Canada. Additionally, social factors are increasing motivations for consumption of locally grown food (Aprile et al., 2016; Penney and Prior, 2014). For instance, consumers are willing to build personal connections with local producers (Zepeda and Leviten-Reid, 2004) and Murphy (2011) discovered that consumers like visiting farmers' market because they can have personal interactions with local producers.

Barriers to locally grown food purchases have been investigated in previous studies. Price was found to be one of the main barriers stopping consumers in the UK from purchasing more locally grown food (Chambers et al., 2007; Penney and Prior, 2014). On the other hand, Dukeshire et al. (2014) discovered that the strongest barrier to the purchase of locally grown food was the "seasonality of local production" in Ontario, Canada. Furthermore, availability (Dukeshire et al., 2014; Onozaka et al., 2010; Penney and Prior, 2014) and convenience (Chambers et al., 2007; Penney and Prior, 2014) were identified as barriers to purchase locally grown food. However, these findings do not imply specific diverse nonlocal consumers. Bond et al. (2008) mentioned that increasing numbers of consumers are different and their preferences are diverse, based on their unique values and culture. This argument supports that drivers and barriers of these diverse communities need to be researched further to accommodate their wants and needs in locally grown food market.

\subsection{Theory of planned behavior (TPB)}

The aim of this research was to examine and compare the factors behind the locally grown food purchase intentions of both domestic and international students. TPB has been chosen as it is a useful empirical predictive tool of intentions and behavior proposed by Ajzen (1991). Therefore, TPB was used to measure the locally grown food purchase intentions of both domestic and international students. TPB has been extrapolated from the theory of reasoned action (TRA) (Fishbein, 1967; Fishbein and Ajzen, 1975). TRA predicts a person's behavior based on attitude and subjective norms (Al-Swidi et al., 2014; Fishbein, 1967; Fishbein and Ajzen, 1975). However, due to a shortcoming of the TRA, i.e. constraints in handling behaviors where individuals have "incomplete volitional control", an additional construct called "perceived behavioral control" was added to TRA (Ajzen, 1991).

TPB assumes that a person's intention to carry out a certain behavior is influenced by a person's attitude, subjective norm and perceived behavior control. First, attitude is "attitude towards the behavior is the degree to which a person has a favorable or unfavorable 
evaluation or appraisal of the behavior in question" (Ajzen, 1991, p. 188). Second, subjective norm is the "perceived social pressure to perform or not to perform the behavior" (Ajzen, 1991, p. 188). Finally, perceived behavioral control is "perceived ease or difficulty of performing the behavior and this is assumed to reflect past experience along with anticipated impediments and obstacles" (Ajzen, 1991, p. 188). Ajzen (1991) explains that when the attitude and subjective norm to behavior are more favorable, and the perceived behavior control is predominant, the intention of an individual to execute the behavior under consideration is stronger in general (Ajzen, 1991).

TPB is a useful and widely used predictive tool among consumer behaviors (Conner and Sparks, 1995), health (Godin and Kok, 1996) and food choice (Alam and Sayuti, 2011; Bianchi and Mortimer, 2013; Campbell, 2013; Vermeir and Verbeke, 2008; Yazdanpanah and Forouzani, 2015). Applying modified models of TRA and TPB, Bianchi and Mortimer (2015) examined factors of locally grown food purchase intention in Chilean and Australian populations. The findings of their study revealed that consumers from both countries with a positive attitude about eating local food are more likely to intend to eat local food. Additionally, in both countries, "attitude toward local agri-businesses" and "consumer ethnocentrism" are found to have a positive effect on attitude toward eating local food. However, ethnocentrism is a more important motivator for Australian consumers as compared to Chilean consumers. On the other hand, Campbell (2013) used a modified TPB to observe locally produced food purchase intentions and behavior differences between Hispanic and Caucasian consumers. Campbell (2013) found that differences exist between Hispanic and Caucasian consumers. For Hispanic consumers, attitudes and product availability constructs were more important as compared to Caucasian consumers. However, Hispanic consumers have more positive attitudes toward locally grown food and greater perceived product availability, but these attitudes did not convert to purchase intention or behavior. For Caucasian consumers, the estimated values of perceived product availability were greater as compared to Hispanic consumers. This reflects greater intention to purchase and greater extent of purchase of locally grown food among Caucasian consumers. Overall, these studies were able to distinguish the locally grown food purchase intentions of consumers using modified TRA and TPB models, which demonstrated that TPB could be effective in measuring student population purchase intentions.

\subsection{Moral norm}

In this study, an additional construct called moral norm is added to the original framework of TPB. Moral or normative issues are considered to have a significant impact on behavior (Etzioni, 1988; Harsanyi, 1982). However, TPB has been criticized for not adequately capturing moral or normative effects on behavior (Armitage and Conner, 2001; Gorsuch and Ortberg, 1983; Sparks and Shepherd, 2002) as "all moral and normative influences on behavior are assumed to be mediated via the measures of subjective norms and attitudes" (Ajzen and Fishbein, 1980, p. 247; Manstead, 2000). Therefore, evidence for the inclusion of moral dimensions in the original TPB is increasing (Ajzen, 1991; Arvola et al., 2008; Conner and Armitage, 1998; Manstead, 2000). Moral norm was introduced by the psychologist Schwartz (1977) from his norm-activation theory of altruism. According to Schwartz (1977), the personal (moral) norm denotes internalized norms and values of significant others that each individual's own perspectives of the right and the wrong have been established through life. Schwartz (1977) stated that pro-environmental actions take place because of reaction to personal moral norms about them. In addition, these actions are initiated by a person who believes he or she can prevent an environmental hazard that threatens other people, species or the biosphere. According to Neuborne and Kerwin (1999), the Millennial Generation in the USA is environmentally conscious. They want fresh and clean products that do not involve 
animal testing and potential environmental damage. Overall, they have a well-developed sense of social responsibility (Farris et al., 2002).

The objective of this study is to observe perceptions of students in the Millennial Generation. Due to this reason, observing the significance of moral norm among Millennial Generation students can discover whether their environmental support is relating to their local food purchasing behavior. Furthermore, previous food and sustainable food consumption research highlighted the importance of including the moral norm construct on the TPB (Arvola et al., 2008; Leeuw et al., 2011; Shepherd et al., 2005; Shin and Hancer, 2016; Yazdanpanah and Forouzani, 2015). For instance, Yazdanpanah and Forouzani (2015) examined Iranian students' intention to purchase organic food. Yazdanpanah and Forouzani (2015) compared an original TPB model and an extended TPB model by adding additional constructs of moral norm and self-identity. These additional constructs were found to be statistically significant, but a subjective norm construct and a perceived behavior control construct were found to be insignificant. In conclusion, this study discovered the importance of moral norm construct when it comes to predict organic food purchase intention of students. Within the similar context of food, this research aims to verify whether moral norm is an effective construct to predict locally grown purchase intention of university students.

\subsection{Hypotheses}

Given the historical and theoretical explanation regarding to the TPB above, an extended model of TPB was proposed. In this study, the context of attitude was defined as the overall perceptions of the locally grown food such as health, quality and support of the local community. All of these were positively linked to locally grown food purchase intention. The context of subjective norms was social influences such as friends, university community and family, and these factors were positively linked to locally grown food purchase intention. The context of perceived product availability was defined as ease of access, identification and availability of locally grown food, and they were positively linked to locally grown food purchase intention. Finally, the context of moral norm was interpersonal obligations within a person, and they were positively linked to locally grown food purchase intention. Based on the model, the following hypotheses were proposed (Figure 1):

H1. There is a positive relationship between attitude and intention to purchase locally grown food.

H2. There is a positive relationship between subjective norms and intention to purchase locally grown food.

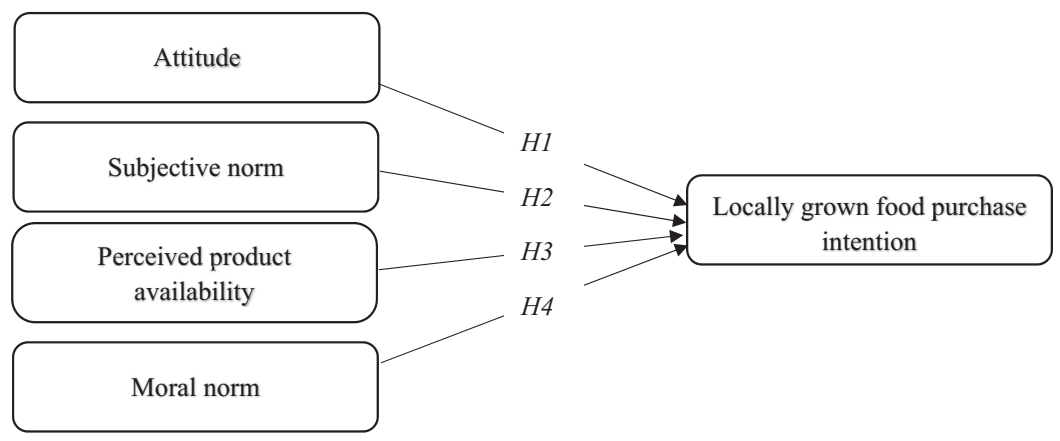

Locally grown food purchase intention 
H3. There is a positive relationship between perceived product availability and intention to purchase locally grown food.

H4. There is a positive relationship between moral norm and intention to purchase locally grown food.

Previous research on local food and students involved only college students in America (Wilkins et al., 2000). Meanwhile, another study that compared the perceptions of locally grown food among various nationalities revealed partial degrees of differences among nationalities (Bianchi and Mortimer, 2015). Because of the inconclusiveness of the findings of previous literature, the following hypotheses were proposed:

H5. There is no difference between domestic and international students' attitude and intention to purchase locally grown food.

H6. There is no difference between domestic and international students' subjective norms and intention to purchase locally grown food.

H7. There is no difference between domestic and international students' perceived product availability and intention to purchase locally grown food.

H8. There is no difference between domestic and international students' moral norm and intention to purchase locally grown food.

\section{Methods}

The research protocol was reviewed and approved by the University Research Ethics Boards (REBs) prior to the study.

\subsection{Sample selection}

A convenience sampling of domestic and international students from Hospitality, Food, and Tourism department classes at a Canadian university was employed, to collect students' perceptions on locally grown food.

\subsection{Survey instrument}

The question about the definitions of locally grown food for this research was based on a Aprile et al.'s (2016) study that addressed the consumers' definitions of locally grown food. Some rewordings were applied to make the definition reflective of distance, province and point-of-sales. For example, "geographic regions" was specified as Ontario and Canada (province) and "Producers" were reworded to "farmer's market" to address how locally grown food is connected with point-of-sales (see Table 1). The question about the definition of locally grown food was designed to allow respondents to select more than one option, which can provide wider ranges of responses on students' perspective of the definition of locally grown food. For the TPB scale, a total of 16 questions used in this research were modified and developed based on previous research and literature on locally grown food. These questions include purchase intention (two items), attitude (five items), subjective norm (three items), perceived product availability (four items) and moral norm (two items).

Questions on purchase intention were modified from Bianchi and Mortimer's (2015) locally grown food purchase intention questions. In this research, specific locations were added such as grocery store and campus. Questions on attitudes toward consuming locally grown food included items that measured important drivers for purchasing locally grown food, such as health, quality and support for farmers. According to Aprile et al. (2016), 58.9\% of consumers from Naples, Italy, believed that locally grown food might have benefits for one's health 
(Aprile et al., 2016). In addition, Eičaitè and Dabkienè (2015) discovered that health concern came as the second driver of consuming locally grown food in Lithuania. From previous findings, the health benefit of locally grown food is critical because it is the most important driver to encourage customers to consume locally grown food (Aprile et al., 2016; Bianchi and Mortimer, 2015; Eičaitè and Dabkienè, 2015). Personal drivers toward locally grown food include enhanced taste, freshness and superiority of produce (Aprile et al., 2016; Bianchi and Mortimer, 2015; Chambers et al., 2007; Murphy, 2011; Penney and Prior, 2014). Consumers recognize locally grown food as fresher (Bruhn et al., 1992; Chambers et al., 2007; Onozaka et al. 2010) and pick freshness as the main driver of locally grown food purchase intentions (Feagan et al.,2004). The question on consumers' opinions on local farmers was modified from Cranfield et al.'s (2012) question: "It is important to support our local farmers" (Cranfield et al., 2012, p. 211).

Questions on subjective norms were modified from Campbell's (2013) questions, and "university community" was added in this research. "Perceived behavioral control construct" was reworded as "perceived product availability construct" to fit the context of this current research. Two questions on perceived product availability were modified from Campbell (2013). Additionally, two questions were developed based on barriers to the locally grown food that were recognized from previous literature include product awareness (Penney and Prior, 2014) and factors related to the Canadian climate. Three questions on moral norms were modified from Yazdanpanah and Forouzani (2015), and the term "organic food" was replaced by "local food" in this research.

The questionnaire used a six-point Likert scale: 1 - strongly disagree, 2 - disagree, 3 somewhat disagree, 4 - somewhat agree, 5 - agree and 6 - strongly agree. A six-point Likert scale was chosen to avoid having an ambiguous midpoint such as "neutral" (Smith, 2010). Such midpoints may be interpreted as "uncertain", "no opinion", "have not thought about it" or some other interpretation that allows the respondent to avoid expressing a view (Smith, 2010). Reverse coding was applied to following five questions: "Local foods are no healthier than imported foods from reputable sources", "Local food is not likely tastier than the same food when imported", "My friends do not care whether or not I purchase local food", "My family do not care whether or not I should purchase local food", "I do not feel an obligation to purchase local food rather than imported food”.

\subsection{Data collection}

The researcher visited and spoke to professors at the School of Hospitality, Food and Tourism department, and they agreed to help distribute the survey to the students in their classes. A total of 218 surveys were distributed at three undergraduate classes. Following the standard ethical guidelines at the university, participation in the survey was voluntary.

\subsection{Data analysis}

Cronbach's alpha is a measure for the reliability of all constructs used in this research. The purchase intention construct consisted of two items $(\alpha=0.72)$, the attitude construct consisted of five items $(\alpha=0.63)$, the subjective norm construct consisted of three items $(\alpha=0.51)$, the perceived availability construct consisted of four items $(\alpha=0.50)$ and the moral norm construct consisted of two items $(\alpha=0.56)$. According to Hinton et al. (2004), 0.7-0.9 indicates high reliability and $0.5-0.7$ indicates moderate reliability.

Data were analyzed using the SPSS 24.0. Descriptive statistics (e.g. mean and standard deviation) were used to describe the demographics of the respondents. Furthermore, it was used to determine the most frequently chosen definition of locally grown food (Table 1). A series of inferential statistics were performed including chi-square, $t$-test and multiple regression analysis. A chi-square test was used to compare the differences between domestic 
and international students' definition of locally grown food. The definition chosen by the student was recoded to " 1 " and " 0 " if not chosen. Multiple regression analysis was used to identify factors associated with the participants' locally grown food purchase intentions. $T$-tests were used to compare the mean scores of attitude, subjective norm, perceived product availability and moral norm between domestic and international students. The statistical significance level was set as $p<0.05$.

\section{Results and discussions}

\subsection{Demographic information}

Of 218 surveys distributed, 196 completed surveys were returned, yielding a response rate of $89 \%$. Of all the respondents, $70.9 \%(n=139)$ were female and $29.1 \%(n=57)$ were male respondents. This sample reflects female students as the dominant population at the School of Hospitality, Food, and Tourism Management program at the sample university. In this survey, domestic students comprise $71.9 \%(n=141)$ and international students comprise $28.1 \%(n=55)$ of the sample. The proportion of international students in this sample also reflects the proportion in the program. Majority of the students classified themselves as junior $56.1 \%(n=110)$, followed by senior $38.8 \%(n=76)$ and sophomore $5.1 \%(n=10)$. The mean age of the respondents was 21.3 years old.

\subsection{Definition of locally grown food}

"Food grown/raised within $100 \mathrm{~km}$ where person lives" was the most commonly chosen at $26 \%(n=113)$. "Grown in the province (e.g. Ontario) person lives" $23.2 \%(n=101)$ was the second most commonly chosen followed by "Food purchased from farmer's market" $(21.8 \%)$ $(n=95)$ (Table 1). In the current study, students used physical distance to describe the definition of locally grown food such as $100 \mathrm{~km}$ and province wide. Additionally, students were more likely to choose smaller distances than larger when defining locally grown food. These results were consistent with previous studies on locally grown food and general consumers which note that distances and origins (provinces) are most commonly used to describe the definition of locally grown food (Brooker et al., 1987; Brown, 2003; Conner et al., 2010; Eičaite and Dabkiene, 2015; Wilkins et al., 2000; Wilkins, 2002; Zepeda and LevitenReid, 2004). Furthermore, more than half $(65 \%)$ of the university students from the USA stated their meaning of the word "local" was based on the place where food was produced (Wilkins et al., 2000). However, in our study, students also appeared to link locally grown food with point-of-sales (farmer's market). Additionally, four participants who selected "other" definition of locally grown food provided their own definition of this term, including "Home grown", "From a nearby farmers who you know", "Products come from Central America" and "From my family farm."

Table 1.

Definition of locally grown food by the research respondents

\begin{tabular}{lrc}
\hline Item & $n^{\mathrm{a}}$ & ${\text { Percent }(\%)^{\mathrm{b}}}^{\mathrm{a}}$ \\
\hline Food grown/raised within 100 km where person lives & 113 & 26.0 \\
Grown in the province (e.g. Ontario) person lives & 101 & 23.2 \\
Food purchased from farmer's market & 95 & 21.8 \\
Verified as Ontario grown (e.g. Foodland Ontario) & 80 & 18.4 \\
Grown in Canada & 42 & 9.7 \\
Other & 4 & 0.9 \\
Total & 435 & 100.0
\end{tabular}

Note(s): ${ }^{a}$ Multiple responses were possible. Therefore, $n$ is more than total number of respondents ${ }^{\mathrm{b}}$ Percentages were calculated using total number of responses 
4.3 Difference between domestic and international students' definition of locally grown food A chi-square test was performed to assess the group difference in the definitions of locally grown food between domestic and international students. There were significant relationships between the students' citizenship and the following definitions: grown in the province (e.g. Ontario) person lives $\left(X^{2}(1, N=196)=5.45, p=0.02\right)$, food grown $/$ raised within $100 \mathrm{~km}$ where person lives $\left(X^{2}(1, N=196)=36.24, p<0.001\right)$ and grown in Canada $\left(X^{2}(1, N=196)=22.40, p<0.001\right)$.

These findings indicated that domestic students more narrowly defined the locally grown food in distances (e.g. province or $100 \mathrm{~km}$ ) as compared to international students (e.g. Canada). This narrow definition may also reflect a difference in perspectives on geography. International students seem to focus more broadly and may have a less nuanced view of Canadian geography in our study. Likewise, Zepeda and Leviten-Reid (2004) were able to discover from their study that the African American conventional group tends to define "local" in a larger geographical area as compared to the Caucasian conventional group. They suggested that it might be based on the perspectives of the participants' larger active personal network. For example, some participants born outside of the USA and from different states may have their networks linked to other states.

\subsection{Multiple regression analysis}

A multiple regression analysis was performed to predict locally grown food purchase intention of students based on attitude, subjective norm, perceived product availability, and moral norm (Cronk, 2012). The results showed that $36 \%$ of variance $\left(R^{2}=0.38, F(5\right.$, $190)=22.98, p<0.001$ ) in a purchase intention (dependent variable) was explained by four independent variables (attitude, subjective norm, perceived product availability and moral norm). Each beta coefficient of independent constructs was assessed to test the hypotheses. The results are presented in Table 2 . The relationship between attitude and a purchase intention revealed a statistically significant pattern $(\beta=0.22, p=0.04)$. Therefore, "H1: There is a positive relationship between attitude and intention to purchase locally grown food" was supported. The relationship between subjective norm and a purchase intention shown a statistically insignificant pattern $(\beta=0.17, p=0.07, \mathrm{~ns})$. For, "H2: There is a positive relationship between subjective norm and intention to purchase locally grown food" was not supported. The relationship between perceived product availability and a purchase intention
Locally grown food purchase intention

\begin{tabular}{lll}
\hline Hypotheses & Statements & Results \\
\hline H1 & $\begin{array}{l}\text { There is a positive relationship between attitude and intention to purchase } \\
\text { locally grown food }\end{array}$ & Supported \\
H2 & $\begin{array}{l}\text { There is a positive relationship between subjective norm and intention to } \\
\text { purchase locally grown food }\end{array}$ & $\begin{array}{l}\text { Not } \\
\text { supported }\end{array}$ \\
H3 & $\begin{array}{l}\text { There is a positive relationship between perceived product availability and } \\
\text { intention to purchase locally grown food }\end{array}$ & Supported \\
H4 & $\begin{array}{l}\text { There is a positive relationship between moral norm and intention to purchase } \\
\text { locally grown food }\end{array}$ & Supported \\
H5 & $\begin{array}{l}\text { There is no difference between domestic and international students' attitude } \\
\text { and intention to purchase locally grown food }\end{array}$ & Not \\
There is no difference between domestic and international students' subjective & Supported \\
H6 & $\begin{array}{l}\text { norm and intention to purchase locally grown food } \\
\text { There is no difference between domestic and international students' perceived }\end{array}$ & Not \\
H7 & product availability and intention to purchase locally grown food & Supported \\
There is no difference between domestic and international students' moral & Supported
\end{tabular}


showed a statistically significant pattern and the relationship was the strongest compared to other constructs $(\beta=0.40, p<0.001)$, so "H3: There is a positive relationship between perceived product availability and intention to purchase locally grown food" was supported. The relationship between moral norm and a purchase intention showed a statistically significant pattern $(\beta=0.25, p=0.001)$. Therefore, "H4: There is a positive relationship between a moral norm and the intention to purchase locally grown food" was supported. The status of students (domestic or international) was a significant predictor of the intention to purchase locally grown food $(\beta=0.62, p<0.001)$, with international students having a higher intention to purchase locally grown food. Table 3 shows the results of the multiple regression analysis.

A $t$-test was used to test subhypotheses to examine the group differences between domestic and international students on all constructs (attitude, subjective norm, perceived product availability and moral norm). The mean score of domestic students ( $M=3.08$, $\mathrm{SD}=0.78)$ was significantly higher than international students $(M=2.80, \mathrm{SD}=0.83)$ in a subjective norm construct; $t(194)=2.23, p=0.03$. This suggests that when it comes to domestic students buying locally grown food relative to international students, domestic students are more concerned about social factors including peers, university community and family. The mean score of domestic students $(M=3.74, \mathrm{SD}=1.13)$ was significantly higher than international students $(M=3.31, \mathrm{SD}=0.87)$ in a moral norm construct; $t(126)=2.86$, $p=0.005$. This indicates that domestic students are more concerned about interpersonal responsibilities compared to international students when it comes to buying locally grown food. Therefore, hypotheses 6 and 8 were supported. However, domestic students $(M=4.30$, $\mathrm{SD}=0.73)$ and international students $(M=4.11, \mathrm{SD}=0.59)$ were not different significantly on attitude construct $t(194)=1.73, p=$ n.s. Likewise, domestic students $(M=4.03$, $\mathrm{SD}=0.75)$ and international students $(M=4.04, \mathrm{SD}=0.72)$ were not different significantly on perceived product availability construct $t(194)=-0.09, p=n$.s. Therefore, hypotheses 5 and 7 were not supported. Our findings align with previous studies, as different perceptions of local foods have been identified between different nationalities (Bianchi and Mortimer, 2015; Campbell, 2013).

The findings indicated that perceived product availability, moral norm and attitude constructs positively influenced the locally grown food purchase intention. Perceived product availability is translated as an ease of access, identification and availability of locally grown food and these factors were positively linked to locally grown food purchase intention of students. Attitude is translated as students' positive attitude related to locally grown food such as health, quality and supports on local community and was positively linked to locally grown food purchase intention. Finally, moral norm is translated as interpersonal obligations within a person and were positively linked to locally grown food purchase intention.

Table 3.

Result of multiple regression coefficients for extended TPB independent constructs

\begin{tabular}{|c|c|c|c|c|}
\hline Independent construct & $\beta$ & $\mathrm{SE}$ & $t$-statistics & $p$ \\
\hline Student status ${ }^{\mathrm{a}}$ & 0.621 & 0.137 & 4.532 & $0.000 * * *$ \\
\hline Attitude & 0.219 & 0.105 & 2.075 & $0.039 *$ \\
\hline Subjective norm & 0.171 & 0.094 & 1.814 & 0.071 \\
\hline Perceived product availability & 0.397 & 0.086 & 4.590 & $0.000 * * *$ \\
\hline Moral norm & 0.248 & 0.074 & 3.359 & $0.001^{* *}$ \\
\hline \multicolumn{5}{|c|}{$\begin{array}{l}\text { Note(s): Dependent variable }- \text { purchase intention } \\
\text { aStudent status refers to whether the respondents were domestic (dummy-coding }=0 \text { ) or international students } \\
\text { (dummy-coding }=1 \text { ) } \\
* * * p<0.001 ; p<0.01 ; * p<0.05\end{array}$} \\
\hline
\end{tabular}


In this research, original constructs from TPB and an additional construct moral norm revealed a positive correlation and statistical significance. This means that extended TPB model maybe an applicable framework to investigate local food purchase intention among students. Similarly, Yazdanpanah and Forouzani (2015) conducted research Iranian students' intention to purchase organic food to compare an original TPB model and an extended TPB model by adding the additional constructs: moral norm and self-identity constructs. Their extended model was able to explain a strong $65 \%$ of organic food purchase intention of Iranian students. These additional constructs were found to be statistically significant, but a subjective norm construct and a perceived behavior control construct were found to be insignificant. On the other hand, Vermeir and Verbeke (2008) found that attitudes, perceived social influences, perceived consumer effectiveness and perceived availability positively influenced young adults' sustainable dairy purchasing intention in Belgium. The most influential variables toward behavioral purchase intention were attitude and perceived availability in their study. This finding aligns with our findings as perceived product availability construct was the most influential variable toward locally grown food purchase intention of students. In conclusion, an extended TPB model appeared useful to predict locally grown food purchase intention of domestic and international students in this research.

\section{Practical and theoretical implications}

The research has some significant practical and theoretical implications. From the practical standpoints, the five key questions addressed by the research findings of this study can be used as a guideline when promoting locally grown food to students.

\subsection{Where can I find it?}

This question was created based on a perceived product availability construct and subjective norm. The perceived product availability construct revealed the strongest effect on intention to purchase locally grown food in the current study. The perceived product availability in this study means ease of access, ease of identification and availability of the locally grown food. In order to reach out or market to student populations effectively, distance to purchase locally grown food should be closer and locally grown products should be made more widely available. The city could host farmer's markets (point-of-sales) on a location close to campus during the academic year. This event can bring the following benefits. First, it can educate students to distinguish what is locally available seasonally. Second, it can provide an opportunity for students to shop easily for locally grown food. Finally, it offers an opportunity to build relationships with local farmers in the area which can help students' locally grown food shopping in the future. Since the results of the study showed that less than one third of the students associated locally grown food with farmer's market, it is important to educate students beforehand on various routes that could gain access to these products. Furthermore, many of the hospitality management programs have the food production or meal management courses in their curriculum. These programs can seek collaboration with local farmers, whether to guest speak or donate fresh produce for students' meal projects. These activities could broaden students' networks and allow them to gain access to some of the locally grown food.

\subsection{When can I find it?}

This question was created based on a perceived product availability construct. One question on perceived product availability construct from the survey was worded as "I would prefer to buy local food but sometimes it is impossible due to Canadian climate." International students may not be as familiar with Canadian climate as compared to domestic students. It is found that international students had a higher intention to purchase locally grown food. Thus, 
informing students of seasonal availability of locally grown food can help international students to understand Canadian climate better and impact their shopping. For this, a university community can create locally grown food awareness week during the academic semester to educate student populations. This could include various activities such as providing information about seasonal availability of locally grown crops in area. For the local food growers and supermarket chain operators, the following message can be displayed at the fresh produce section of the market: "Locally grown asparagus, peaches, corns, and strawberries are available during summer, eat local and support local farmers.”

\subsection{Who grows it?}

This question was created based on an attitude construct. One of the questions in this research emphasizes that "It is important as a student at the [name of the university] to support local farmers and our local business in [name of an area]." It is found that the attitude construct positively influenced locally grown food purchase intention. Therefore, knowing the local farmers in the area can help students to understand the importance of supporting locally grown food and their businesses. In order to achieve this, information of local farmers and benefit of supporting local community can be include in marketing messages to evoke positive attitudes among students. For example, the following message can be considered: "Grilling season is back, we are serving 100 percent local-beef burgers, and a variety of condiments made from fresh locally grown food at the dining hall, come join us, eat local, and support [names of the local farms] in our community!"

\subsection{How can I benefit others?}

This question was made based on a moral norm construct. The objective of this study was observing the significance of moral norm and Millennial Generation students, whether their environmental support is related to their locally grown food purchase intention. It is found that the moral norm construct positively influenced the locally grown food purchase intention of the students. According to Neuborne and Kerwin (1999), the Millennial Generation (collegeage group) in the USA are brought up environmentally conscious, they want fresh and clean products that does not involve animal testing and potential damage on ozone layer quality. Overall, they are socially responsible (Farris et al., 2002). In this research, domestic students are more concerned about interpersonal responsibilities as compared to international students when it comes to buying locally grown food. There might be a communication gap between international students and the concept of locally grown food. Therefore, including such messages on environmental benefits of locally grown food (e.g. less travel distances can encourage pro-environmental actions to students to purchase locally grown food) can be considered during the marketing campaign.

\subsection{Why is it good for me?}

This question was created based on an attitude construct. The attitude construct positively influenced locally grown food purchase intention in the current study. An attitude in this study means overall perception of the locally grown food such as health, quality and support of local community. These attributes were previously recognized as the personal drivers to locally grown food including taste, freshness and superiority of produce (Bianchi and Mortimer, 2015; Chambers et al., 2007; Murphy, 2011; Penney and Prior, 2014). The health benefit of locally grown food is critical because this was acknowledged by other researchers as one of the important drivers that encourage consumers to consume locally grown food (Bianchi and Mortimer, 2015; Eičaitè and Dabkienè, 2015). Emphasizing this personal benefit of locally grown food in marketing messages will greatly enhance reaching out efforts to the student consumers. 
Theoretically, this study has several contributions. First, this study utilized TPB, plus an additional variable (moral norm) to predict locally grown food purchase intention of students. Such topic has not been well researched in previous study. Therefore, the conceptual model of this study may add to the body of literature by capitalizing personal attitudes and values to explain locally grown food purchase intention. It turned out that moral norm was influential on locally grown food purchasing intention, suggesting that this variable could be an extension to TPB. Second, this study further confirmed the role of attitude as significant predictor of intention to purchase locally grown food, which may imply that installing favorable attitude toward locally grown food could be a good starting point to motivate young consumers' to purchase locally grown food in the future. However, it is critical to ensure the young consumers aware that the locally grown food is available for their purchase, as product available was the one of the strongest predictors of future purchase intention.

\section{Limitations and future research recommendations}

This study contributed to the current literature about locally grown food by discovering locally grown food purchase intention of domestic and international students although it is necessary to look at the limitations. First, a convenience sampling method was used to recruit students from three classes within the School of Hospitality, Food and Tourism at a Canadian university. Therefore, the results of this study may not be generalized beyond this population. Because of the convenience sampling method, the sample size was small for international students. To increase the number of international students, the researchers can visit a few more courses in the undergraduate programs and encourage students to participate in this study (Kang, 2016). Second, there was a possibility of underrepresentation of certain origins of international student populations by using a convenience sample because the majority of international students at the sample university are from China. However, this research did not ask the respondents to indicate their country of origin. Future studies may include such a question to better identify how students from various countries perceived locally grown food differently. Third, the undergraduate respondents were from the School of Hospitality, Food and Tourism. Thus, they are more likely to have stronger perspectives on the importance of locally grown food and environmental sustainability than other students not from this program. In order to gain a more holistic view on locally grown food among domestic and international students, future research may include students from other departments and conduct a comparative study on this topic. Despite the limitations with sampling as discussed above, the sample size of this study was comparable with other studies that used students as research participants in the hospitality management programs (e.g. Poole et al., 2021; Wang and Teng, 2019). Furthermore, the composition of the participants, such as more than $70 \%$ being females were also similar with recent studies among undergraduate hospitality management students from different countries (i.e. Patiar et al., 2020; Sisson et al., 2020) and was reflective of general enrollment pattern of students in the hospitality management program.

Another limitation is that the four variables in this study (i.e. attitudes, subjective norms, perceived product availability and moral norm) only explained $36 \%$ of the variance of this model. Hence, future studies can expand the scope of this study by adding variables that have been identified in previous literature that may also predict purchase intention, such as commitment to locally grown food and support for the environment (Mirosa and Lawson, 2012).

\section{Conclusions}

The purpose of this research was to examine the definition and to predict locally grown food purchase intentions of domestic and international students at university located in Ontario, Canada. There was a significant difference between domestic and international students on 
definition of locally grown food. Overall, students defined locally grown food based on the distances. However, domestic students narrowly defined the local food in distance compared to international students, for instance domestic students defined locally grown food as "food grown/raised within $100 \mathrm{~km}$ where person lives", as compared to international students who defined that as "food grown in Canada".

Hypotheses were tested by using multiple regression analysis. The multiple regression analysis discovered that $36 \%$ of variance in purchase intention is explained by four independent variables in the proposed model. Perceived product availability, moral norm and attitude constructs positively influenced the locally grown food purchase intention. A perceived product availability construct revealed the strongest influence in locally grown food purchase intention of students. International students had a higher intention to purchase locally grown food. Domestic students are more concerned about social factors (e.g. peers, university community and family) and interpersonal obligations as compared to international students when it comes to buying locally grown food. The moral norm construct positively influenced the locally grown food purchase intention in this study, and this construct seemed useful to predict locally grown food purchase intention of students in the current study. Current research findings verified that there is a significant use of a moral norm construct to predict locally grown food purchase intention of students. Additionally, the research discovered that there were differences in domestic and international students' perception in the locally grown food definition.

\section{References}

Ajzen, I. (1991), "The theory of planned behavior", Organizational Behavior and Human Decision Processes, Vol. 50 No. 2, pp. 179-211.

Ajzen, I. and Fishbein, M. (1980), Understanding Attitudes and Predicting Behavior, Prentice-Hall, Englewood Cliffs, NJ.

Al-Swidi, A., Mohammed Rafiul Huque, S., Haroon Hafeez, M. and Noor Mohd Shariff, M. (2014), “The role of subjective norms in theory of planned behavior in the context of organic food consumption”, British Food Journal, Vol. 116 No. 10, pp. 1561-1580.

Alam, S. and Sayuti, N. (2011), "Applying the theory of planned behavior (TPB) in halal food purchasing", International Journal of Commerce and Management, Vol. 21 No. 1, pp. 8-20.

Aprile, M.C., Caputo, V. and Nayga, R.M., Jr (2016), "Consumers' preferences and attitudes toward local food products", Journal of Food Products Marketing, Vol. 22 No. 1, pp. 19-42. No.

Armitage, C.J. and Conner, M. (2001), "Efficacy of a minimal intervention to reduce fat intake", Social Science and Medicine, Vol. 52 No. 10, pp. 1517-1524.

Arvola, A., Vassallo, M., Dean, M., Lampila, P., Saba, A., Lähteenmäki, L. and Shepherd, R. (2008), "Predicting intentions to purchase organic food: the role of affective and moral attitudes in the Theory of Planned Behavior", Appetite, Vol. 50 No. 2, pp. 443-454.

Bianchi, C. and Mortimer, G. (2015), "Drivers of local food consumption: a comparative study", British Food Journal, Vol. 117 No. 9, pp. 2282-2299.

Bond, C.A., Thilmany, D. and Keeling Bond, J. (2008), "Understanding consumer interest in product and process-based attributes for fresh produce”, Agribusiness, Vol. 24 No. 2, pp. 231-252.

Brooker, J., Eastwood, D.B. and Orr, R.H. (1987), "Consumers' perceptions of locally grown produce at retail outlets", Journal of Food Distribution Research, Vol. 18 No. 1, pp. 99-107.

Brown, C. (2003), "Consumers' preferences for locally produced food: a study in southeast Missouri”, American Journal of Alternative Agriculture, Vol. 18 No. 04, pp. 213-224.

Bruhn, C., Vossen, P., Chapman, E. and Vaupel, S. (1992), "Consumer attitudes toward locally grown produce”, California Agriculture, Vol. 46 No. 4, pp. 13-16. 
Bueckert, K. (2018), “Ontario's university students want quality, local food, report finds”, available at: https:/www.cbc.ca/news/canada/kitchener-waterloo/ontario-university-campus-food-mealexchange-report-card-1.4479638 (accessed 18 April 2021).

Campbell, J.M. (2013), "Muy local: differentiating Hispanic and Caucasian shoppers of locally produced foods in US grocery", Journal of Retailing and Consumer Services, Vol. 20 No. 3, pp. 325-333.

Cbie-Bcei (2020), "International students in Canada continue to grow in 2019", available at: https://cbie. ca/international-students-in-canada-continue-to-grow-in-2019/ (accessed 18 April 2021).

Chambers, S., Lobb, A., Butler, L., Harvey, K. and Traill, W.B. (2007), "Local, national and imported foods: a qualitative study", Appetite, Vol. 49 No. 1, pp. 208-213.

Conner, M. and Armitage, C.J. (1998), "Extending the theory of planned behavior: a review and avenues for further research", Journal of Applied Social Psychology, Vol. 28 No. 15, pp. 1429-1464. No.

Conner, M. and Sparks, P. (1995), “The Theory of planned behavior and health behaviors”, in Conner, M. and Normal, P. (Eds), Predicting Health Behavior: Research and Practice with Social Cognition Models, Open University Press, Buckingham.

Conner, D., Colasanti, K., Ross, R.B. and Smalley, S.B. (2010), "Locally grown foods and farmers markets: consumer attitudes and behaviors", Sustainability, Vol. 2 No. 3, pp. 742-756.

Cranfield, J., Henson, S. and Blandon, J. (2012), "The effect of attitudinal and socio demographic factors on the likelihood of buying locally produced food", Agribusiness, Vol. 28 No. 2, pp. 205-221.

Cronk, B.C. (2012), How to Use SPSS Statistics: A Step-by-step Guide to Analysis and Interpretation, $7^{\text {th }}$ ed., Pyrczak Pub, Gelndale, CA.

Dodds, R., Holmes, M., Arunsopha, V., Chin, N., Le, T., Maung, S. and Shum, M. (2014), “Consumer choice and farmers' markets", Journal of Agricultural and Environmental Ethics, Vol. 27 No. 3, pp. 397-416.

Dukeshire, S., Masakure, O., Mendoza, J., Holmes, B. and Murray, N. (2014), "Understanding consumer choices for Ontario produce", Renewable Agriculture and Food Systems, pp. 1-11.

Eičaite, O. and Dabkienè, V. (2015), "Local food: lithuanian consumers' perceptions and attitudes", Scientific Papers Series Management, Economic Engineering in Agriculture and Rural Development, pp. 65-70.

Etzioni, A. (1988), The Moral Dimension: Towards a New Economics, Free Press, New York.

Farris, R., Chong, F. and Danning, D. (2002), "Generation Y: purchasing power and implications for marketing", Academy of Marketing Studies Journal, Vol. 6 Nos 1-2, p. 89.

Feagan, R. (2007), "The place of food: mapping out the 'local' in local food systems", Progress in Human Geography, Vol. 31 No. 1, pp. 23-42.

Feagan, R., Morris, D. and Krug, K. (2004), 'Niagara region farmers' markets: local food systems and sustainability considerations", Local Environment, Vol. 9 No. 3, pp. 235-254.

Fishbein, M.E. (1967), Readings in Attitude Theory and Measurement, Wiley, New York.

Fishbein, M. and Ajzen, I. (1975), Belief, Attitude, Intention, and Behavior: an Introduction to Theory and Research, Addison-Wesley, Reading, MA.

Godin, G. and Kok, G. (1996), "The theory of planned behavior: a review of its applications to healthrelated behaviors", American Journal of Health Promotion, Vol. 11 No. 2, pp. 87-98.

Gorsuch, R.L. and Ortberg, J. (1983), "Moral obligation and attitudes: their relation to behavioral intentions", Journal of Personality and Social Psychology, Vol. 44 No. 5, pp. 1025-1028.

Government of Canada. Canadian Food Inspection Agency. Food Labelling and Claims Directorate. (2014), "Local food claims interim policy", available at: http://www.inspection.gc.ca/food/labelling/ food-labelling-for-industry/origin/local-food-claims/eng/1368135927256/1368136146333 (accessed 30 January 2021). 
Harsanyi, J.C. (1982), "Utilitarianism and beyond", in Sen, A. and Williams, B. (Eds), Morality and the Theory of Rational Behavior, Cambridge University Press, Cambridge, pp. 39-62.

Herrin, M. and Gussow, J.D. (1989), "Designing a sustainable regional diet”, Journal of Nutrition Education, Vol. 21 No. 6, pp. 270-275.

Hinton, P., Brownlow, C., McMurray, I. and Cozens, B. (2004), SPSS Explained, Routledge, New York.

Jones, P., Comfort, D. and Hillier, D. (2004), “A case study of local food and its routes to market in the UK”, British Food Journal, Vol. 106 No. 4, pp. 328-335.

Kang, J. (2016), "Incentivizing survey participation: best practices and recommendations", available at: https://offices.depaul.edu/student-affairs/about/assessment/Documents/Incentivizing_Survey_ Participation_Report\%20_July_2016.pdf (accessed 12 April 2021).

Kenny, M. (2014), “A campus food revolution at University of Guelph”, available at: https:/hospitality. uoguelph.ca/sites/uoguelph.ca.hospitality/files/public/A-Campus-Food-Revolution-at-theUniversity-of-Guelph.pdf (accessed 30 January 2021).

Lang, M., Stanton, J. and Qu, Y. (2014), “Consumers' evolving definition and expectations for local foods", British Food Journal, Vol. 116 No. 11, pp. 1808-1820.

Leeuw, A.D., Valois, P. and Houssemand, C. (2011), "Predicting the intentions to buy fair-trade products: the role of attitude, social norm, perceived behavioral control, and moral norm", OIDA International Journal of Sustainable Development, Vol. 2 No. 10, pp. 77-84.

Manstead, A.S.R. (2000), "The role of moral norm in the attitude-behavior relation", in Terry, D.J. and Hogg, M.A. (Eds), Attitudes, Behavior, and Social Context: The Role of Norms and Group Membership. Applied Social Research, Lawrence Erlbaum Associates, Mahwah, NJ, pp. 11-30.

Martinez, S., Hand, M., Da Pra, M., Pollack, S., Ralston, K., Smith, T., Vogel, S., Clark, S., Lohr, L., Low, S. and Newman, C. (2010), "Local food systems: concepts, impacts, and issues", Department of Agriculture, Economic Research Service, ERR 97, p. 87.

Maynard, M., Lahey, D. and Abraham, A. (2018), "Campus food report card: the state of food on Ontario university campuses", available at: https://d3n8a8pro7vhmx.cloudfront.net/ greenbeltfund/pages/3103/attachments/original/1558709276/Campus_Food_Report_Card_-Full_Release.pdf?1558709276 (accessed 30 January 2021).

Mirosa, M. and Lawson, R. (2012), "Revealing the lifestyles of local food consumers", British Food Journal, Vol. 114 No. 6, pp. 816-825.

Morris, C. and Buller, H. (2003), "The local food sector: a preliminary assessment of its form and impact in Gloucestershire", British Food Journal, Vol. 105 No. 8, pp. 559-566.

Murphy, A.J. (2011), "Farmers' markets as retail spaces", International Journal of Retail and Distribution Management, Vol. 39 No. 8, pp. 582-597.

Neuborne, E. and Kerwin, K. (1999), "Population and marketing brand name products", Business Week, p. 80, (February 15).

Onozaka, Y., Nurse, G. and McFadden, D.T. (2010), "Local food consumers: how motivations and perceptions translate to buying behavior", Choices, Vol. 25 No. 1, pp. 1-6.

Patiar, A., Kensbock, S., Benckendorff, P., Robinson, R., Richardson, S., Wang, Y. and Lee, A. (2020), "Hospitality students' acquisition of knowledge and skills through a virtual field trip experience", Journal of Hospitality and Tourism Education, Vol. 33 No. 1, pp. 14-28.

Pearson, D., Henryks, J., Trott, A., Jones, P., Parker, G., Dumaresq, D. and Dyball, R. (2011), "Local food: understanding consumer motivations in innovative retail formats", British Food Journal, Vol. 113 No. 7, pp. 886-899.

Penney, U. and Prior, C. (2014), "Exploring the urban consumer's perception of local food", International Journal of Retail and Distribution Management, Vol. 42 No. 7, pp. 580-594.

Poole, S.M., Maier, T.A., Wiss, B. and Smith, S. (2021), "Game-based learning in wine education", Journal of Hospitality and Tourism Education, pp. 1-6. 
Pretty, J. (2001), "Some benefits and drawbacks of local food systems", Briefing note, TVU/Sustain AgriFood Network, University of Essex, Essex, 2 November.

Sacks, J. (2002), The Money Trail: Measuring Your Impact on the Local Economy Using LM3, Vol. 128, New Economics Foundation, London.

Schwartz, S.H. (1977), "Normative influences on altruism", Advances in Experimental Social Psychology, Academic Press, Vol. 10, pp. 221-279.

Shepherd, R., Magnusson, M. and Sjödén, P.O. (2005), "Determinants of consumer behavior related to organic foods", AMBIO: A Journal of the Human Environment, Vol. 34 No. 4, pp. 352-359.

Shin, Y.H. and Hancer, M. (2016), "The role of attitude, subjective norm, perceived behavioral control, and moral norm in the intention to purchase local food products", Journal of Foodservice Business Research, Vol. 19 No. 4, pp. 338-351.

Sisson, A., Grisamore, A. and Jang, J. (2020), "Green practices with reusable drinkware at music and sporting events: a hospitality undergraduate student perspective", Journal of Hospitality and Tourism Education, Vol. 33 No. 1, pp. 1-13.

Smith, S.L. (2010), Practical Tourism Research, CABI, Cambridge University Press, Cambridge.

Sparks, P. and Shepherd, R. (2002), "The role of moral judgments within expectancy-value-based attitude-behavior models", Ethics and Behavior, Vol. 12 No. 4, pp. 299-321.

Statista Research Department (2015a), "Share of consumers who make an effort to buy locally grown food in Canada as of May 2015", available at: https://www.statista.com/statistics/ 442102/consumers-who-make-an-effort-to-buy-locally-grown-food-canada/ (accessed 30 January 2021).

Statista Research Department (2015b), "Share of consumers who are willing to pay more for locally grown and produced food in Canada as of June 2015", available at: https:/www.statista.com/ statistics/435621/consumers-willing-to-pay-more-for-locally-grown-food-in-canada/ (accessed 30 January 2021).

Statista Research Department (2015c), "Best places to buy local food products according to consumers in Canada as of May 2015", available at: https:/www.statista.com/statistics/436169/best-placesto-buy-local-food-products-according-to-consumers-canada/ (accessed 30 January 2021).

Statista Research Department (2015d), "Barriers to buying local food and beverage products among consumers in Canada as of May 2015", available at: https://www.statista.com/statistics/436122/ barriers-to-buying-local-food-and-beverage-products-canada/ (accessed 30 January 2021).

United States Department of Agriculture, National Agricultural Library (2021), "Local foods as of june 2021", available at: https://www.nal.usda.gov/aglaw/local-foods\#quicktabs-aglaw_ pathfinder $=0$ (accessed 17 June 2021).

Vermeir, I. and Verbeke, W. (2008), "Sustainable food consumption among young adults in Belgium: theory of planned behavior and the role of confidence and values", Ecological Economics, Vol. 64 No. 3, pp. 542-553.

Wang, Y. and Teng, C. (2019), "Transformative sustainability learning model for inculcating passion for learning about green food and beverage inhospitality college students", Journal of Teaching in Travel and Tourism, Vol. 19 No. 4, pp. 302-325.

Weatherell, C., Tregear, A. and Allinson, J. (2003), "In search of the concerned consumer: UK public perceptions of food, farming and buying local", Journal of Rural Studies, Vol. 19 No. 2, pp. 233-244.

Wilkins, J.L. (2002), "Consumer perceptions of seasonal and local foods: a study in a US community", Ecology of Food and Nutrition, Vol. 41 No. 5, pp. 415-439.

Wilkins, J.L., Bokaer-Smith, J. and Hilchey, D. (1996), Local Foods and Local Agriculture: A Survey of Attitudes Among Northeastern Consumers, Project report, Division of Nutritional Sciences, Cornell Cooperative Extension, New York.

Wilkins, J.L., Bowdish, E. and Sobal, J. (2000), "University student perceptions of seasonal and local foods", Journal of Nutrition Education, Vol. 32 No. 5, pp. 261-268.
Locally grown food purchase intention 
Wisconsin Local Food Marketing Guide (2014), "A producer's Guide to marketing locally grown food, third edition as of 2014", available at: https://datcp.wi.gov/Documents/DAD/ LocalMarketingFoodGuide_1_16.pdf (accessed 15 June 2021).

Yazdanpanah, M. and Forouzani, M. (2015), "Application of the Theory of Planned Behavior to predict Iranian students' intention to purchase organic food", Journal of Cleaner Production, Vol. 107, pp. 342-352.

Zepeda, L. and Leviten-Reid, C. (2004), "Consumers' views on local food”, Journal of Food Distribution Research, Vol. 35 No. 3, pp. 1-6.

\section{Corresponding author}

Yoonah Kim Conoly can be contacted at: yoontoaha@gmail.com

For instructions on how to order reprints of this article, please visit our website: www.emeraldgrouppublishing.com/licensing/reprints.htm Or contact us for further details: permissions@emeraldinsight.com 